\title{
Scoring for determining effect of antimuscarinics
}

\author{
Viroj Wiwanitkit
}

Received: 5 June 2010 / Accepted: 8 June 2010 / Published online: 19 June 2010

(C) The International Urogynecological Association 2010

\section{Dear Editor,}

I read the recent publication by Panayi et al. with great interest [1]. The authors concluded that "The mechanism of action of antimuscarinics appears to be a complex interaction of sensory and motor components". I have a few questions on this work. I wonder if many investigators have used subjective scores in this work, especially the Patient Perception of Bladder Condition questionnaire and visual analogue scales, that can lead to conclusions regarding the

V. Wiwanitkit $(\bowtie)$

Wiwanitkit House,

Bangkhae, 10160 Bangkok, Thailand

e-mail: wviroj@yahoo.com actual biological processes, either motor or sensory. If Panayi et al. concluded the existence of a complex interaction, there must be supportive evidence showing that proposed interrelationship.

Conflicts of interest None.

\section{References}

1. Panayi DC, Tekkis P, Fernando R, Khullar V (2010) Is the beneficial effect of antimuscarinics related to motor or sensory changes in the bladder? Int Urogynecol J Pelvic Floor Dysfunct 21 (7):841-845. doi:10.1007/s00192-010-1123-3 